\title{
POOLED RECORDS FROM MULTIPLE SOURCES FOR MONITORING CONGENITAL ANOMALIES
}

\author{
BY \\ HOWARD B. NEWCOMBE \\ Biology and Health Physics Division, Atomic Energy of Canada Limited, Chalk River, Ontario
}

Interest in finding out how many children are handicapped as the result of prenatal influence which might possibly be avoided has increased in recent years, but systems for reporting congenital anomalies have been disappointing. A birth population may sometimes be regarded as well documented because most of the children with anomalies are known to at least one of the various health agencies or treatment services. However, unless such information about the affected individuals finds its way to a single location, it is not possible to derive unduplicated counts of the total numbers of children involved. The extent to which this is true in the Canadian province of Nova Scotia will be illustrated by data from the records of three largely independent sources, namely the hospital insurance system, the vital records system, and a registry for handicapped children.

The main incentive for recent schemes of so-called 'monitoring' or 'surveillance' of the rates at which congenital anomalies occur stems from the thalidomide incident, and from the fear that this might be followed by other similar incidents. Such schemes have emphasized the desirability of early reporting. However, recognition of the consequences of prenatal damage is not always possible at an early stage. To cite an extreme example, the onset of leukaemia due to radiography of the mother prior to the birth may occur at any time over the first decade of life. Presumably other harmful influences may have similarly delayed consequences.

The purposes for which data on children with congenital anomalies are compiled may thus include:

(a) Detection of an upswing in the frequency of one of the anomalies (as with the phocomelia induced by thalidomide);

(b) Identification of particular prenatal influences that may cause anomalies, especially where the expression of the damage is delayed in its occurrence (as with the induction of leukaemia of childhood by prenatal irradiation); and

(c) Follow-up of the affected children to ensure that none will lack necessary treatment through oversight.

The relative ease with which information on individual cases in the province of Nova Scotia may be pooled from the various relevant files makes it possible to identify an unusually high proportion of the children with congenital anomalies in that province. The present investigation deals with children born in 1964 and followed through 1968.

\section{SOURCES AND METHODS}

For the present study, information on children with congenital anomalies, born in Nova Scotia in1964, has been obtained through the Nova Scotia Chapter of the Canadian Rehabilitation Council for the Disabled, from their Central Register of Handicapped Children. This information has been pooled with that from case discharge summaries of the Nova Scotia Hospital Insurance Commission and the vital registration system for the province, obtained for the purposes of an earlier study (Newcombe, 1969).

For the earlier study, records of hospital discharges during the first year of life, and of infant deaths, were merged into a single file in which the affected children were identified by name, birth date, and geographic area of residence. A total of 18,314 children who were born alive in Nova Scotia in 1964 were screened in this way for anomalies, and a few additional cases from among $\mathbf{2 6 0}$ stillborn children were found from the published statistics. (The population of Nova Scotia in 1964 was 763,000.) The study was greatly simplified by the fact that the large files of hospital discharge records for the province of Nova Scotia (i.e., more than 100,000 per year) exist as punchcards and magnetic tape, and some use was also made of the similar mechanization of the death registrations.

The pooling of records from these two sources yielded, in the earlier study, better reporting of affected infants than had been achieved elsewhere through the use of a variety of single sources such as (a) the routine 'physician's notification of birth 
forms' for the Canadian province of Ontario (Ontario Department of Health, 1966), (b) a special world-wide hospital survey of congenital anomalies among newborn infants (Stevenson, Johnston, Stewart, and Golding, 1966), and (c) special registers of congenital anomalies, such as those of the cities of Liverpool and Birmingham (Smithells, 1968).

At the time when the earlier investigation was planned, use of the records of the Nova Scotia Central Registry of Handicapped Children in that study was not seriously considered. The reason was that the records were not in punchcard form and were thus less rapidly manipulable. However, the success with which affected children were identified through the other two sources over a single year of life led to speculation concerning the possible numbers of further children having the same conditions that might be known to this Registry.

A request to the Registry yielded a list of some 514 children with various conditions, born in 1964 and registered to the end of 1968. This list had been extracted manually from the files, in typewritten form. The list was compared visually with a mechanically produced listing from the hospital and death punchcards in order to distinguish the new cases from those that were already known from the earlier list. The matching was done on the basis of names, birth-dates, and counties of residence. In all, 381 previously unidentified children were represented in the Registry list, of whom 240 had congenital anomalies of the kinds selected for the earlier study. These conditions also occurred in 127 children from the Registry list who had already been identified through the hospital and death records.

The manual labour in this operation would have been greatly reduced had the records of the Central Registry of Handicapped Children been available in machine-readable form. In fact, it is not difficult to imagine a simple routine system whereby data from all three sources could be integrated annually, with virtually no clerical work, to yield an unduplicated list of affected children.

\section{Results}

The extent to which the use of more than one kind of source record increases the efficiency of case finding is indicated in Table $I$, and in greater detail in Table VIII. Of the 733 children with congenital anomalies of the selected kinds, a third (240) fail to appear in the hospital insurance and death records, and half (366) are unknown to the Central Registry of Handicapped Children.

The Registry itself performs a major task of integrating reports of congenital anomalies from a wide range of sources. These include:

(1) Halifax Children's Hospital

(2) Department of Public Health

(3) School for the Deaf

TABLE I

NUMBERS OF CASES OF CONGENITAL ANOMALIES REPORTED AMONG NOVA SCOTIA CHILDREN BORN IN 1964 (i.e., Unduplicated Counts of Affected Children)

\begin{tabular}{|c|c|c|c|c|c|c|}
\hline \multirow[b]{2}{*}{ Code } & \multirow[b]{2}{*}{ Anomaly } & \multicolumn{3}{|c|}{ No. of Cases } & \multirow[b]{2}{*}{ Total Cases } & \multirow[b]{2}{*}{$\begin{array}{c}\text { Rate per } 1,000 \\
\text { Live Births }\end{array}$} \\
\hline & & $\begin{array}{l}\text { From Hospital } \\
\text { and Death } \\
\text { Records }\end{array}$ & $\begin{array}{l}\text { Additional } \\
\text { from Registry }\end{array}$ & $\begin{array}{c}\text { Re- } \\
\text { ascertainments }\end{array}$ & & \\
\hline $\begin{array}{l}253 \\
295 \\
325 \\
384\end{array}$ & $\begin{array}{l}\text { Cretinism } \\
\text { Haemophilia } \\
\text { Mental deficiency } \\
\text { Strabismus }\end{array}$ & $\frac{3}{29}$ & $\begin{array}{r}-1 \\
49 \\
66\end{array}$ & $\stackrel{1}{9}_{1 * 0}$ & $\begin{array}{r}3 \\
1 \\
78 \\
66\end{array}$ & $\begin{array}{l}0.16 \\
0.05 \\
4.26 \\
3.60\end{array}$ \\
\hline $\begin{array}{l}389 \\
397 \\
745 \\
748\end{array}$ & $\begin{array}{l}\text { Blindness } \\
\text { Deafmutism } \\
\text { Curvature of the spine } \\
\text { Clubfoot }\end{array}$ & $\frac{-}{1}$ & $\frac{1}{33}$ & $\frac{1}{1}$ & $\begin{array}{r}1 \\
57\end{array}$ & $\begin{array}{l}\overline{0-05} \\
0-05 \\
3 \cdot 11\end{array}$ \\
\hline $\begin{array}{l}750 \\
751 \\
752 \\
753\end{array}$ & $\begin{array}{l}\text { Monstrosity } \\
\text { Spina bifida and meningocele } \\
\text { Fydrocephalus } \\
\text { Other c.m. of nervous system }\end{array}$ & $\begin{array}{l}10 \\
25 \\
21 \\
11\end{array}$ & $\begin{array}{r}-1 \\
5 \\
3\end{array}$ & $\begin{array}{r}10 \\
- \\
\end{array}$ & $\begin{array}{l}10 \\
26 \\
26 \\
14\end{array}$ & $\begin{array}{l}0.55 \\
1.42 \\
1.42 \\
0.76\end{array}$ \\
\hline $\begin{array}{l}754 \\
755 \\
756 \\
757\end{array}$ & $\begin{array}{l}\text { C.m. of circulatory system } \\
\text { Cleft palate and hare lip } \\
\text { C.m. of digestive system } \\
\text { C.m. of genito-urinary system }\end{array}$ & $\begin{array}{r}76 \\
33 \\
138 \\
21\end{array}$ & $\begin{array}{r}31 \\
7 \\
3 \\
1\end{array}$ & $\begin{array}{r}30 \\
26 \\
3 \\
-\end{array}$ & $\begin{array}{r}107 \\
40 \\
141 \\
22\end{array}$ & $\begin{array}{l}5 \cdot 84 \\
2 \cdot 18 \\
7 \cdot 70 \\
1 \cdot 20\end{array}$ \\
\hline \multirow[t]{2}{*}{$\begin{array}{l}758 \\
759 \\
-\end{array}$} & $\begin{array}{l}\text { C.m. of bone and joint } \\
\text { Other and unspecified c.m. } \\
\text { Multiple congenital anomalies }\end{array}$ & $\begin{array}{l}31 \\
50 \\
20\end{array}$ & $\begin{array}{r}19 \\
6 \\
14\end{array}$ & $\begin{array}{r}6 \\
1 \\
18\end{array}$ & $\begin{array}{l}50 \\
56 \\
34\end{array}$ & $\begin{array}{l}2 \cdot 73 \\
3 \cdot 06 \\
1 \cdot 86\end{array}$ \\
\hline & Total & 493 & 240 & 127 & 733 & 40.02 \\
\hline
\end{tabular}

-Also looked for but not found : hallux valgus and varus (code 747), and other deformities (code 749)

- Different diagnosis on earlier records (i.e., codes 252 and $753 \cdot 1$ respectively)

c.m. = congenital malformations 
TABLE II

YEAR OF LIFE IN WHICH CASES OF CONGENITAL ANOMALIES WERE REGISTERED WITH THE CENTRAL REGISTRY OF HANDICAPPED CHIDREN FROM THE 1964 BIRTH POPULATION

\begin{tabular}{|c|c|c|c|c|c|c|}
\hline \multirow{2}{*}{ Code } & \multirow{2}{*}{ Anomaly } & \multicolumn{5}{|c|}{ Year of Life in which Cases were Registered } \\
\hline & & 1st & 2nd & 3rd & 4th & Total Cases \\
\hline $\begin{array}{l}253 \\
295 \\
325 \\
384\end{array}$ & $\begin{array}{l}\text { Cretinism } \\
\text { Haemophilia } \\
\text { Mental deficiency } \\
\text { Strabismus }\end{array}$ & $\begin{array}{r}1 \\
-1 \\
1\end{array}$ & $\overline{7}$ & $\overline{\overline{18}}$ & $\begin{array}{l}\overline{1} \\
14 \\
33\end{array}$ & $\begin{array}{r}1 \\
58 \\
67\end{array}$ \\
\hline $\begin{array}{l}389 \\
397 \\
745 \\
748\end{array}$ & $\begin{array}{l}\text { Blindness } \\
\text { Deafmutism } \\
\text { Curvature of the spine } \\
\text { Clubfoot }\end{array}$ & $\frac{1}{23}$ & $\bar{z}$ & $\begin{array}{l}\overline{1} \\
1 \\
7\end{array}$ & $\bar{z}$ & $\begin{array}{r}1 \\
1 \\
1 \\
47\end{array}$ \\
\hline $\begin{array}{l}750 \\
751 \\
752 \\
753\end{array}$ & $\begin{array}{l}\text { Monstrosity } \\
\text { Spina bifida and meningocele } \\
\text { Hydrocephalus } \\
\text { Other c.m. of nervous system }\end{array}$ & $\begin{array}{r}10 \\
5 \\
-\end{array}$ & $\begin{array}{l}-1 \\
3 \\
2\end{array}$ & $\overline{\frac{7}{1}}$ & $\frac{-}{2}$ & $\begin{array}{l}\overline{11} \\
\mathbf{1 1} \\
\mathbf{3}\end{array}$ \\
\hline $\begin{array}{l}754 \\
755 \\
756 \\
757\end{array}$ & $\begin{array}{l}\text { C.m. of circulatory system } \\
\text { Cleft palate and hare lip } \\
\text { C.m. of digeative system } \\
\text { C.m. of genito-urinary system }\end{array}$ & $\begin{array}{r}25 \\
22 \\
3 \\
-\end{array}$ & $\begin{array}{r}15 \\
11 \\
2 \\
-\end{array}$ & $\underline{9}$ & $\frac{12}{1}$ & $\begin{array}{r}61 \\
33 \\
6 \\
1\end{array}$ \\
\hline $\begin{array}{l}758 \\
759 \\
-\end{array}$ & $\begin{array}{l}\text { C.m. of bone and joint } \\
\text { Other and unspocified c.m. } \\
\text { Multiple congenital anomalies }\end{array}$ & $\begin{array}{r}7 \\
2 \\
15 \\
\end{array}$ & $\begin{array}{l}6 \\
2 \\
9\end{array}$ & $\begin{array}{l}9 \\
\mathbf{1} \\
\mathbf{3}\end{array}$ & $\begin{array}{l}3 \\
2 \\
5\end{array}$ & $\begin{array}{r}25 \\
7 \\
32\end{array}$ \\
\hline & Total & 123 & 91 & 76 & 77 & 367 \\
\hline
\end{tabular}

(4) Crippled Children's Clinics (i.e., mobile clinics run by the Nova Scotia Society for the Care of Crippled Children)

(5) Halifax Infirmary

(6) Halifax Social Service Department

(7) Grace Maternity Hospital

(8) Children's Aid Society

(9) Local hospitals (i.e., in the children's own counties of residence)

(10) Speech and Hearing Clinic

(11) Ontario Society for Crippled Children and Adults

(12) Provincial Department of Welfare

However, no single organization, as yet, has systematic access to the three major sources used in the present study, so the extent of the routine integration of data is considerably less than is possible.

From the present data for children born in 1964, at least 40 per 1000 liveborn are known to be affected by congenital anomalities of the selected kinds. This proportion is considerably higher than has been reported from other studies, and more detailed comparisons will be made later in this report.

Of the children who were known to the Central Registry as affected by the selected anomalies, most had been registered during the first year or two of life, with the notable exceptions of those with mental deficiency and strabismus (Table II). Comparable data for cases identified through the hospital insurance and death records are available from the earlier study only over the first year of life. How many additional cases would have become known
TABle III

MULTIPLE CONGENITAL ANOMALIES AMONG CHILDREN REGISTERED WITH THE CENTRAL REGISTRY OF HANDICAPPED CHILDREN FROM THE 1964 BIRTH POPULATION

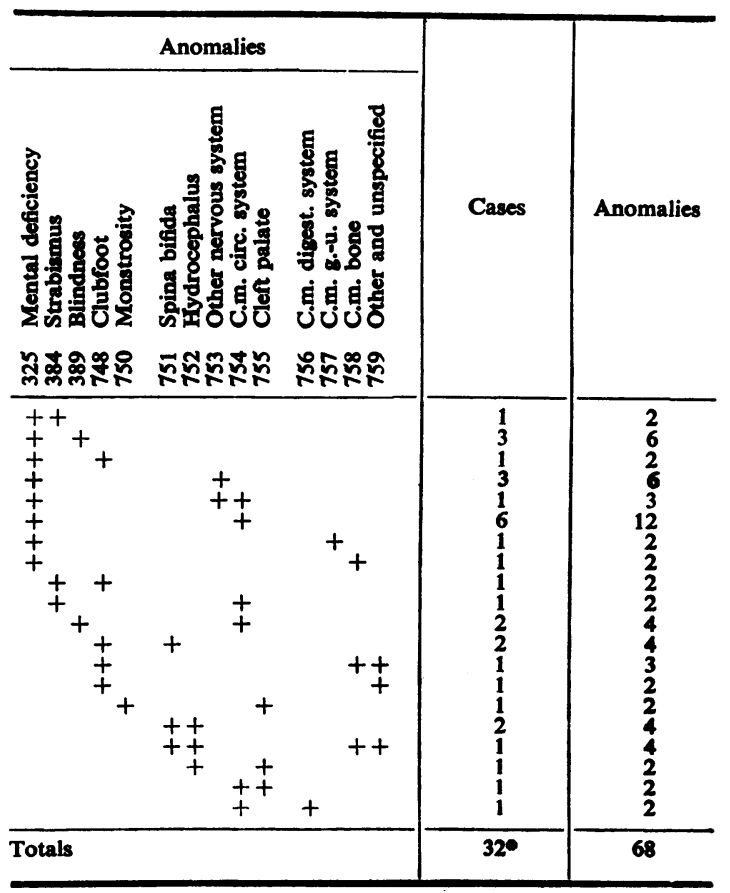

Plus one with unspecified multiple malformitions 
TABLE IV

NUMBERS OF CONGENITAL ANOMALIES REPORTED AMONG NOVA SCOTIA CHILDREN BORN IN 1964

(Rates per 1,000 Liveborn Compared with Those for the City of Liverpool)

\begin{tabular}{|c|c|c|c|c|c|c|}
\hline \multirow[b]{2}{*}{ Code } & \multirow[b]{2}{*}{ Anomaly } & \multicolumn{3}{|c|}{ No. of Anomalies } & \multicolumn{2}{|c|}{ Rates per 1,000 Live Births } \\
\hline & & $\begin{array}{l}\text { From Hospital } \\
\text { and Death } \\
\text { Records }\end{array}$ & $\begin{array}{l}\text { Additional } \\
\text { from } \\
\text { Registry }\end{array}$ & Total & $\begin{array}{l}\text { Nova Scotia } \\
\text { (reg. to } \\
\text { age 4-5) }\end{array}$ & $\begin{array}{l}\text { Liverpool } \\
\text { (reg. to } \\
\text { age 5-6) }\end{array}$ \\
\hline $\begin{array}{l}253 \\
295 \\
325 \\
384\end{array}$ & $\begin{array}{l}\text { Cretinism } \\
\text { Haemophilia } \\
\text { Mental deficiency } \\
\text { Strabismus }\end{array}$ & $\frac{4}{32}$ & $\begin{array}{r}-1 \\
66 \\
69\end{array}$ & $\begin{array}{r}4 \\
1 \\
98 \\
70\end{array}$ & $\begin{array}{l}0 \cdot 2 \\
0 \cdot 1 \\
5 \cdot 4 \\
3 \cdot 8\end{array}$ & $\overline{1.4}$ \\
\hline $\begin{array}{l}389 \\
397 \\
745 \\
748\end{array}$ & $\begin{array}{l}\text { Blindness } \\
\text { Deafmutism } \\
\text { Curvature of the spine } \\
\text { Clubfoot }\end{array}$ & $-\frac{1}{3}$ & $\begin{array}{r}5 \\
1 \\
39\end{array}$ & $\begin{array}{r}6 \\
1 \\
3 \\
66\end{array}$ & $\begin{array}{l}0 \cdot 3 \\
0 \cdot 1 \\
0 \cdot 2 \\
3 \cdot 6\end{array}$ & $\bar{z}$ \\
\hline $\begin{array}{l}750 \\
751 \\
752 \\
753\end{array}$ & $\begin{array}{l}\text { Monstrosity } \\
\text { Spina bifida and meningocele } \\
\text { Hydrocephalus } \\
\text { Other c.m. of nervous system }\end{array}$ & $\begin{array}{l}13 \\
32 \\
31 \\
17\end{array}$ & $\begin{array}{l}1 \\
6 \\
9 \\
7\end{array}$ & $\left.\begin{array}{l}14 \\
38 \\
40 \\
24\end{array}\right\} 116$ & $\left.\begin{array}{l}0 \cdot 8 \\
2 \cdot 1 \\
2 \cdot 2 \\
1 \cdot 3\end{array}\right\}$ & $7 \cdot 1$ \\
\hline $\begin{array}{l}754 \\
755 \\
756 \\
757\end{array}$ & $\begin{array}{l}\text { C.m. of circulatory system } \\
\text { Cleft palate and hare lip } \\
\text { C.m. of digestive system } \\
\text { C.m. of genito-urinary system }\end{array}$ & $\begin{array}{r}89 \\
35 \\
143 \\
30\end{array}$ & $\begin{array}{r}43 \\
10 \\
4 \\
2\end{array}$ & $\begin{array}{r}132 \\
45 \\
147 \\
32\end{array}$ & $\begin{array}{l}7 \cdot 2 \\
2 \cdot 5 \\
8 \cdot 0 \\
1 \cdot 7\end{array}$ & $\begin{array}{l}5 \cdot 0 \\
1.5 \\
1.7 \\
2 \cdot 6\end{array}$ \\
\hline \multirow[t]{2}{*}{$\begin{array}{l}758 \\
759\end{array}$} & $\begin{array}{l}\text { C.m. of bone and joint } \\
\text { Other and unspecified c.m. }\end{array}$ & $\begin{array}{l}35 \\
67\end{array}$ & $\begin{array}{r}22 \\
9\end{array}$ & $\begin{array}{l}57 \\
76\end{array}$ & $\begin{array}{l}3 \cdot 1 \\
4 \cdot 1\end{array}$ & $\begin{array}{l}4 \cdot 1 \\
2 \cdot 5\end{array}$ \\
\hline & Totals & 560 & 294 & $854 *$ & $46 \cdot 6$ & $28 \cdot 6$ \\
\hline
\end{tabular}

Includes mongoliam only; the Nova Scotia data include 22 cases of mongolism or $1 \cdot 2$ per thousand liveborn

- Representing 733 affected children

had these sources been employed beyond age 1 year is not known.

The 32 cases of multiple afflictions of selected kinds, from the Registry records, yielded a total of 68 individual anomalies in various combinations (Table III). Only where two or more different threedigit disease codes were applied to the same child was the case regarded as one of multiple anomalies. If the fourth digit had been used, or if different conditions reported on separate records had been included, the numbers would have been larger. Comparable data for multiple anomalies ascertained through the hospital and death records are presented in the earlier paper.

Comparisons are made with the numbers of anomalies found by a special registration system set up in the British City of Liverpool (Table IV, and Smithells, 1968). If the comparison is restricted to those kinds of disease which are represented in the Liverpool study, the rates for total anomalies per 1000 live births become 37.6 and 28.6 for Nova Scotia and Liverpool respectively. Where unduplicated counts of affected children, rather than anomalies, are compared, the comparable rates are $33.0(605 / 18,314)$ and $23.9(2,183 / 91,176)$. The unusually high frequency of congenital malformations of the digestive system reported in the hospital records for Nova Scotia has not been fully investigated, but the difference is still substantial even if this group of conditions is ignored. Presumably the differences would have been greater still if the Nova Scotia hospital and death records had been employed beyond the first year of life.

The choice of conditions that are to be regarded as congenital is to some degree arbitrary, and the use of too restrictive a selection could result in possible failure to detect some important trend or cause-and-effect relationship. Conditions that might have been included in the list but were not, and which are known to the Central Registry of Handicapped Children, are shown in Tables V to VII.

TABLE V

ADDITIONAL CONDITIONS OF GENETIC ORIGIN* (Central Registry of Handicapped Children)

\begin{tabular}{|c|c|c|}
\hline Code & Anomaly & No. of Cases \\
\hline \multirow[t]{2}{*}{$\begin{array}{l}192 \\
272 \\
289 \\
587 \\
732 \\
744 \\
744\end{array}$} & $\begin{array}{l}\text { Retinoblastoma } \\
\text { Diabetes insipidus } \\
\text { Phenylketonuria } \\
\text { Cystic fibrosis } \\
\text { Legs-Perthes' disease } \\
\text { Muscular dystrophy } \\
\text { Congenital amyotonia }\end{array}$ & $\begin{array}{l}1 \\
1 \\
1 \\
\mathbf{1} \\
1 \\
1 \\
\mathbf{1}\end{array}$ \\
\hline & Total & 15 \\
\hline
\end{tabular}

-All are listed as hereditary in McKusick (1960)

Hereditary diseases (Table V) come within most definitions of congenital anomalies because the casual circumstances are undoubtedly present at birth whether the disease can be detected then or 
TABLE VI

ADDITIONAL CONDITIONS WITH A POSSIBLE HEREDITARY OR CONGENITAL COMPONENT* (Central Registry of Handicapped Children)

\begin{tabular}{c|l|c}
\hline Code & \multicolumn{1}{|c|}{ Condition } & No. of Cases \\
\hline 204 & Leukaemia & 3 \\
241 & Asthma & 47 \\
244 & Eczema & 1 \\
245 & Allergy & 4 \\
270 & Hypoglycaemia & 1 \\
277 & Precocious puberty & 1 \\
289 & Idiopathic aminoacidopathy & 1 \\
299 & Blood dyscrasia & 2 \\
326 & Speech defect & 2 \\
351 & Cerebral palsy & 14 \\
353 & Epilepsy & 12 \\
380 & Deficient vision & 6 \\
398 & Deafness & 3 \\
398 & Impaired hearing & 1 \\
560 & Inguinal hernia & 1 \\
- & Multiple & 4 \\
\hline & Total & 103 \\
\hline
\end{tabular}

- Of the more specifically diagnosed conditions, most are listed in McKusick (1966) as sometimes hereditary

* The four cases represent the following combinations of conditions

(1) reticuloendotheliosis, xanthomatosis, glycogen storage;

(2) hypoglycaemia, cerebral palsy;

(3) eczema, epilepsy, deafness;

(4) rheumatoid arthritis, malignant teratoma

not. Other conditions, which in a proportion of cases are believed to be either hereditary or influenced by the prenatal environment, are shown in Table VI. For the tumours and cysts listed in Table VII there is little direct evidence of a congenital origin, except where these are actually observed at birth or shortly thereafter. However, in view of the long periods of latency between exposures to known carcinogens and the occurrence of the
TABLE VII

ADDITIONAL TUMOURS AND CYSTS SOME OF WHICH MAY BE CONGENITAL IN ORIGIN (Central Registry of Handicapped Children)

\begin{tabular}{c|l|c}
\hline Code & \multicolumn{1}{|c}{ Condition } & No. of Cases \\
\hline 180 & Kidney cancer & 1 \\
180 & Wilms tumour & 1 \\
196 & Cystic bone disease & 1 \\
217 & Growth on external genitalia & 1 \\
220 & Multiple pigmented naevi \\
223 & Tumour of the eye & 1 \\
223 & Cerebral cyst & 1 \\
228 & Haemangioma of the scalp & 1 \\
\hline & Total & 1 \\
\hline
\end{tabular}

tumours they induce, and in particular the delay between fetal irradiation and the resulting leukaemia, it would seem surprising if the causes of most tumours of early childhood were not prenatal.

When all of the conditions in the foregoing tables are considered, and when congenital malformations of stillborn children (from the stillbirth registrations) are included, it may be said that the integrated records represent 48 affected individuals and 56 anomalies per 1000 live births, in the 1964 birth cohort followed over a period of four to five years (Table VIII).

\section{Discussion}

The success of this attempt to integrate records from three major sources to determine the numbers of congenitally handicapped children raises questions about the feasibility of similar routine manipulation of existing health records.

TABLE VIII

FREQUENCIES OF CASES AND OF ANOMALIES IN THE 1964 BIRTH POPULATION FROM ALL SOURCES COMBINED

\begin{tabular}{|c|c|c|c|c|c|c|}
\hline \multirow{2}{*}{ Anomalies and Source Records" } & \multicolumn{2}{|c|}{ Numbers } & \multicolumn{2}{|c|}{ Cumulative Totals } & \multicolumn{2}{|c|}{$\begin{array}{c}\text { Rates per } 1,000 \\
\text { Live Births }\end{array}$} \\
\hline & Cases & Anom. & Cases & Anom. & Cases & Anom. \\
\hline $\begin{array}{l}\text { Selected List of Anomalies } \\
\text { Hospital records (to age 1) } \\
\text { New cases from death records (to age 1) } \\
\text { (Repeat ascertainments) } \\
\text { New cases from registry (to age 5) } \\
\text { (Repeat ascertainments) } \\
\text { Stilibirth registrations (previous report) }\end{array}$ & $\begin{array}{r}458 \\
35 \\
(65) \\
240 \\
(127) \\
24\end{array}$ & $\begin{array}{r}560 \\
308 \\
24\end{array}$ & $\begin{array}{l}458 \\
493 \\
\frac{733}{757}\end{array}$ & $\begin{array}{l}\overline{560} \\
\overline{868} \\
\overline{892}\end{array}$ & $\begin{array}{l}25 \cdot 0 \\
26.9 \\
40 \cdot 0 \\
41 \cdot 3\end{array}$ & $\frac{3 \overline{30}}{\overline{47 \cdot 4}}$ \\
\hline $\begin{array}{l}\text { Other Anomalies from Registry } \\
\text { Genetic conditions (Table V) } \\
\text { Partially genetic or congenital (Table VI) } \\
\text { Tumours and cysts (Table VII) }\end{array}$ & $\begin{array}{r}15 \\
103 \\
8\end{array}$ & $\begin{array}{r}15 \\
109 \\
8\end{array}$ & $\begin{array}{l}772 \\
875 \\
883\end{array}$ & $\begin{array}{r}907 \\
1,016 \\
1,024\end{array}$ & $\begin{array}{l}42 \cdot 2 \\
47.8 \\
48.2\end{array}$ & $\begin{array}{l}49.5 \\
55.5 \\
56.0\end{array}$ \\
\hline
\end{tabular}

The above groups of conditions omit the following cases from the Central Registry of Handicapped Children:

$\begin{aligned} 293 & \text { Secondary anaemia } \\ 334 & \text { Organic brain damage } \\ 378 & \text { Dacryocystitis } \\ 400 & \text { Rheumatic fever } \\ 590-600 & \text { Nephritis and nephrosis } \\ 730 & \text { Osteomyelitis } \\ 761 & \text { Erb's paralysis } \\ \mathbf{7 7 2} & \text { Failure to thrive } \\ 940-949 & \text { Scalds and burns } \\ & \text { Total }\end{aligned}$


The largest of the three files is currently the easiest to use. The Nova Scotia hospital insurance punchcards are already on magnetic tape, complete with name, birthdate, county of residence in coded form, up to two disease codes, and the date of discharge. It is simple to extract from such tape files a smaller file of selected records corresponding to the cases of special interest. The death records are also in machine-readable form with personal identifying information, although with only the underlying cause of death coded so that clerical work is required to obtain from the registration forms information on anomalies other than those given as underlying causes of death.

The smallest of the three source files, the Central Register of Handicapped Children, is not yet on punchcards, and therefore required more clerical work. The cost of converting a file of this size to machine-readable form is, of course, small by almost any standard. In the long run, however, the deciding factor in such matters may be the extent to which integrated sources of health data in general are thought to have merit.

Such integrations have been actively discussed in some Canadian provinces, and are the subject of a recent report published by the Medical Research Council of Canada (1968). The increased application of modern data processing methods to medical record keeping, for purposes of economy and convenience, has resulted in similar discussions in other countries (for reviews see Acheson, 1967, 1968). With so many records now being handled by computers, it has become technically feasible for the first time to treat the individuals as the important units when handling their medical records, rather than the various agencies among whom these records happen to be scattered.

In relation to congenital anomalies, it may be said that the children of Nova Scotia are very well documented, if only the documents could be gathered together. The same might be true of other regions, but in Nova Scotia the difficulties are reduced by the presence of personal identifying information on the hospital discharge tapes, and by the work done by the Central Registry of Handicapped Children.

\section{SUMMARY}

The numbers of children with congenital anomalies among the 1964 birth cohort in the Canadian province of Nova Scotia have been studied using three existing and independently derived files of records. These are the hospital insurance magnetic tape records of case discharges and the vital registrations of stillbirths and deaths, both to the end of the first year of life, plus those of a central register of handicapped children to the end of 1968.

Unduplicated counts of affected children could be obtained from the pooled records because all of them identified the individual children by name, birthdate, and area of residence. The combined records showed that as many as 48 children per 1000 liveborn are affected by conditions that might be regarded as congenital. Comparisons with other surveys indicate clearly that the present use of multiple sources can result in higher levels of identification of cases than are likely to be achieved through any one source alone.

The labour of extracting the required information from the three kinds of files varied inversely with their size. The file of hospital discharge records for the province, which is by far the largest of the three, was the easiest to tap because it can be read by high speed computers and identifies the individuals concerned. Some use could also be made of the machine-readable versions of the death registrations. However, access to the relatively small register of handicapped children depended entirely on manual clerical work.

The problem of pooling information routinely from all the major relevant sources is discussed.

I should like to thank the Nova Scotia Hospital Services Commission, the Department of Health of Nova Scotia, and the Nova Scotia Chapter of the Canadian Rehabilitation Council for the Disabled for permission to use the various records of cases of congenital anomalies. In addition, I am indebted to the Health and Welfare Division of the Dominion Bureau of Statistics for the substantial labour of preparing the tabular data from the hospital and death records for the purposes of the earlier study, and to the Nova Scotia Chapter of the Canadian Rehabilitation Council for the Disabled for the very considerable work of preparing manually in list form a copy of the relevant portions of records in their files. I should also like to thank Miss Martha Smith for help in planning and carrying out both studies.

Use of the vital and health records was at all times in strict accordance with the oath of secrecy respecting the non-statistical information contained in the records.

\section{REFERENCES}

ACHESON, E. D. (1967). Medical Record Linkage. Oxford University Press, London, New York, Toronto.

- (Ed.). (1968). Record Linkage in Medicine; Proceedings of the International Symposium, Oxford, July, 1967. Livingstone, Edinburgh and London.

McKusick, V. A. (1966). Mendelian Inheritance in Man. Johns Hopkins Press, Baltimore.

Medical Research Council of Canada (1968). Health Research Uses of Record Linkage in Canada. Report No. 3 of the Medical Research Council of Canada, Ottawa. 
Newcombe, H. B. (1969). The value of Canadian hospital insurance records for detecting increases in congenital anomalies. Canad. med. Ass. J., in press.

Ontario Department of Health. (1966). Congenital Anomalies Reported by Physicians. Live Births and Stillbirths, Ontario, 1964. Special Report No. 28, of the Ontario Department of Health, Toronto.
SmItHells, R. W. (1968). Incidence of congenital abnormalities in Liverpool, 1960-64. Brit. J. prev. soc. Med., 22, 36.

Stevenson, A. C., Johnston, H. A., Stewart, M. I. P., and GoldING, D. R. (1966). Congenital Malformationsi A Report of a Study of Series of Consecutive Births in 24 Centres. Supplement to Vol. 34 of the Bulletin of the World Health Organization, Geneva. 